\title{
Morphological and chromosomal aberrations during embryonic development in dab Limanda limanda
}

\author{
P. Cameron, J. Berg \\ Biologische Anstalt Helgoland, Notkestr. 31, W-2000 Hamburg 52, Germany
}

\begin{abstract}
During the Bremerhaven Workshop, ichthyoplankton samples were collected with horizontal subsurface hauls at 28 stations from the inner German Bight to the Dogger Bank. Directly after being caught fish embryos were examined alive for morphological developmental defects under a dissecting microscope. Investigations on chromosomal aberrations were confined to preserved blastula stages of $\mathrm{dab}$ and were carried out later in the laboratory. Main species sampled were dab Limanda limanda, plaice Pleuronectes platessa, sprat Sprattus sprattus and whiting Merlangius merlangus. Because of their widespread distribution and high numerical occurrence, dab embryos were best suited for the detection of regional differences in malformation frequencies. The proportion of malformations in the most sensitive early developmental stage of dab reached $32 \%$ in the inner part of the German Bight and fell to $9 \%$ further offshore, increasing again at the Dogger Bank to values up to $31 \%$. Data collection was accomplished with a computerized data sampling/evaluation/presentation system, and results concerning the morphological differences of malformation frequencies were available directly after observation. Thus, the method as described below proved to be a suitable approach for biological effects monitoring. Anaphase aberration frequencies in dab embryos reached a peak of $63 \%$ in the inner part of the German Bight, whereas the lowest value $(51 \%)$ was detected far offshore at a less polluted station; aberrations on the Dogger Bank were found to be $57 \%$. Investigations on the chromosomal aberrations in the same material used for the determination of morphological aberrations provided an opportunity to evaluate the potential effects of contaminants at the chromosome level.
\end{abstract}

\section{INTRODUCTION}

Biological effects such as morphological developmental defects and chromosomal aberrations that may reduce the chances of survival of an individual, a population or even a species are suitable parameters for monitoring purposes. Embryonic defects which may result in an impairment in reproduction, one of the most critical activities in the life cycle of a species, should be interpreted as a pollution index of particular significance for affected species in the observed area. Reproduction in many of the commercially important North Sea fish takes place in coastal waters which are generally considered to be the most polluted areas of the North Sea (Kersten et al. 1988, Lohse 1990).

Lipophilic organic contaminants accumulate on their way through the food web, especially in fatty tissue. In the case of fish, the concentration factor with respect to polychlorinated biphenyls (PCB) in the water column may reach 80000 (Bruggeman et al. 1981). During vitellogenesis, the stored substances may be transported with the lipid reserves from the liver or other somatic tissue to the developing gonads (Dawson \& Grimm 1980, Delahunty \& de Vlaming 1980, Knickmeyer \& Steinhart 1989). Experiments show that concentrations of several chlorinated hydrocarbons, e.g. PCB, DDE and Dieldrin, found in natural flatfish populations lead to malformations during embryonic development which reduce hatching success (Westernhagen et al. 1981, 1989, Hansen et al. 1985, Spies et al. 1988). This is only one group of many potential toxicants that may produce the biological effects which are the focus of this investigation. 

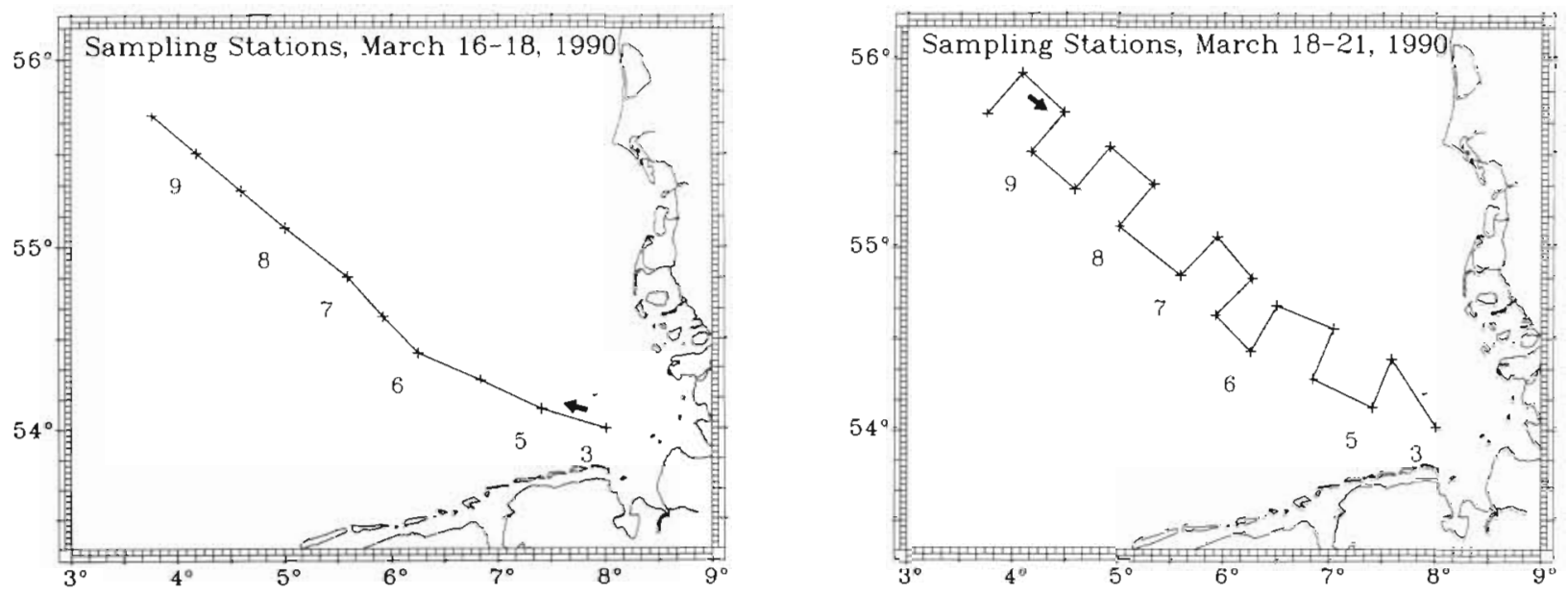

Fig. 1. Sampling stations for the investigation of morphological malformations in pelagic fish embryos in March 1990
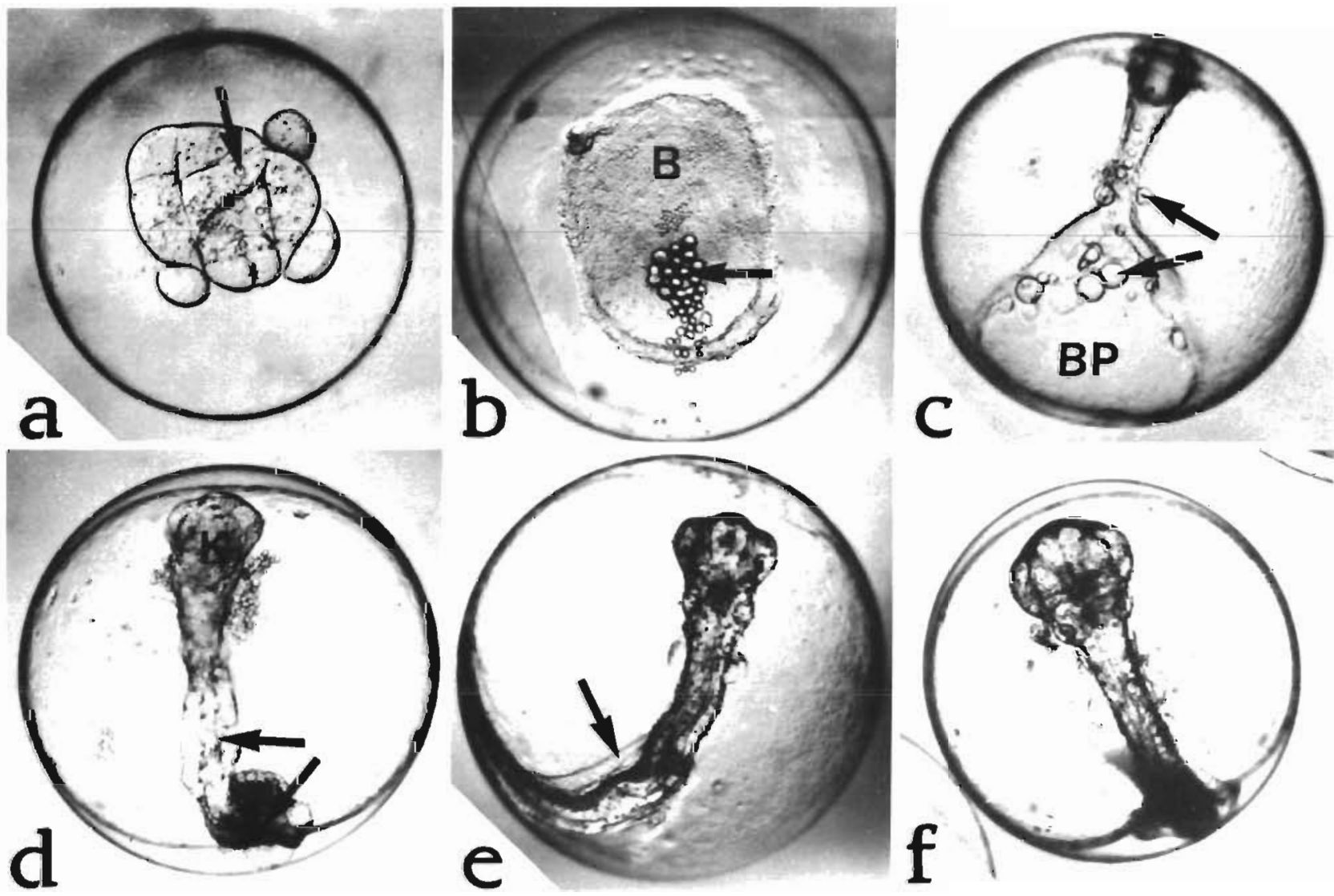

Fig. 2. Malformations during embryonic development of pelagic flatfish eggs. (a to c) Malformatıons during the early development and the differentiation processes: (a) deformation of blastomeres in 16-cell stage with inner formation of blisters; (b) underdeveloped early gastrulation with abnormal blastodisc (B) shape and severe incorporation of blisters; (c) young embryo with severe blister formation unable to close blastopore (BP). (d to f) Malformations in older embryos: (d) faulty differentiation in the head region, proliferation. twisting of the body and crippled tail; (e) crippled notochord; (f) formation of blisters in further developed fish embryo 


\section{MATERIAL AND METHODS}

In March 1990, pelagic fish eggs were caught at 28 stations (Fig. 1) in the southeastern part of the North Sea, using a plankton net (CALCOFI, $1 \mathrm{~m} \varnothing, 300 \mu \mathrm{m}$ mesh) towed horizontally just below the surface for $10 \mathrm{~min}$. Because morphological aberrations from the normal embryonic development can only be detected in undamaged embryos, towing speed had to be less than $1 \mathrm{knot}$, since high towing speeds of 4 knots or more are known to cause damage and up to $92 \%$ mortality in fish eggs (Southward \& Demir 1974). Samples were concentrated in the cod end of the net (plankton beaker) and poured into glass vessels containing sea water. After a few minutes, the embryos rose to the surface, where they were sorted for microscopic analysis. At each station, 500 to 1350 eggs per sample were examined on cooled dishes directly after the catch. Morphological aberrations were detected under a dissecting microscope at 25- to 32-fold magnification. After microscopical analysis, the remaining eggs were preserved in $10 \%$ buffered formalin for chromosome analysis.

Eggs were determined according to species, developmental stage and morphological aberrations from normal development. Five different stages of embryonic development were differentiated: (Ia) early cleavages until the formation of the blastodisc; (Ib) epiboly, the building of the embryonic shield and the axes; (II) differentiation of the embryo, formation of the head and growth around the yolk (up to $180^{\circ}$ ); (III) embryo between $180^{\circ}$ and $270^{\circ}$ around yolk with further differentiation; (IV) embryo between $270^{\circ}$ and $360^{\circ}$ around yolk, tail free, body movements.

Development was considered defective if stages deviated from normal development and morphological differentiation. Some common abnormalities are shown in Fig. 2. During the first cell divisions incomplete and irregular cleavage may ensue, leading to deformations of the blastomeres and to abnormal shapes of the blastodisc. Wrinkles and blisters inside and on the surface of cells may occur, as well as gastrulae with loose cell aggregates. Differentiation of the embryo may be retarded in certain parts of the body and the closure of the blastopore may be disturbed. In older embryos, blister-like outcrops from body axis, bent notochords, twisting of the tail, deformations of the head region, fin abnormalities, defects of the eyes and pigmentation anomalies may be recognized. The relevance of these registered malformations to embryo survival is known from incubation experiments with egg samples from the western Baltic (Westernhagen et al. 1988). There, low hatching success coincided with high malformation frequencies at the respective stations. In addition, incubation experiments with indivi- dual embryos could show that $85 \%$ of the registered malformations were lethal within $5 \mathrm{~d}$ (Cameron unpubl.).

For chromosome analysis the blastula-embryos of dab were dissected from chorion and yolk, stained with aceto-orcein and squashed on microscope slides. Anaphase aberrations such as attached and free fragments as well as bridges, leading to an unequal distribution of chromatid material between the dividing cells, were counted at 1000 -fold magnification.

\section{RESULTS}

The species occurring in the winter ichthyoplankton of the southern North Sea were, in descending abundance: dab Limanda limanda, plaice Pleuronectes platessa, sprat Sprattus sprattus, whiting Merlangius merlangius, rockling, Onos sp., flounder Platichthys flesus, cod Gadus morhua, long rough dab Hippoglossoides platessoides and dragonet Callionymus lyra. Eggs of L. limanda constituted one-third of all fish eggs in number and occurred at each station. Due to the decreasing sensitivity of the embryos with ongoing development (especially after the closure of the blastopore), and the loss of aberrant embryos due to selective mortality, the observed frequencies of malformations declined as development progressed. Values for $L$. $I$ manda decreased from $22.9 \%$ (stage Ia) to $1.1 \%$ (stage IV), for $P$ platessa from $6.2 \%$ to $1.9 \%$, for $S$. sprattus from $43.2 \%$ to $6.2 \%$ and for $M$. merlangus from $28.7 \%$ to $6.8 \%$. In addition, there existed species-specific differences in the occurrence of malformation frequencies. The most severely affected species was $M$. merlangus, showing a mean aberration frequency of $24 \%$, followed by S. sprattus with $20 \%$, whereas mean malformation frequencies in L. limanda and $P$. platessa with $6 \%$ and $5 \%$ respectively were much lower.

When looking for regional differences in malformation frequencies, early stages were preferred as they reflect the condition of the ovary from which the unfertilized egg is released, and as advection effects are minimized. Studies should therefore concentrate on the first cleavage stages before the closure of the blastopore (Ia to II), which takes about $2 \mathrm{~d}$ after fertilization depending on water temperature. Furthermore, species with widespread distribution of their early developmental stages are best suited for the detection of regional differences in malformation frequencies. Therefore we chose Limanda limanda embryos for comparison of malformation frequencies between different stations.

Malformation frequencies in very young Limanda limanda embryos (stage la) were found to reach $30.1 \%$ 

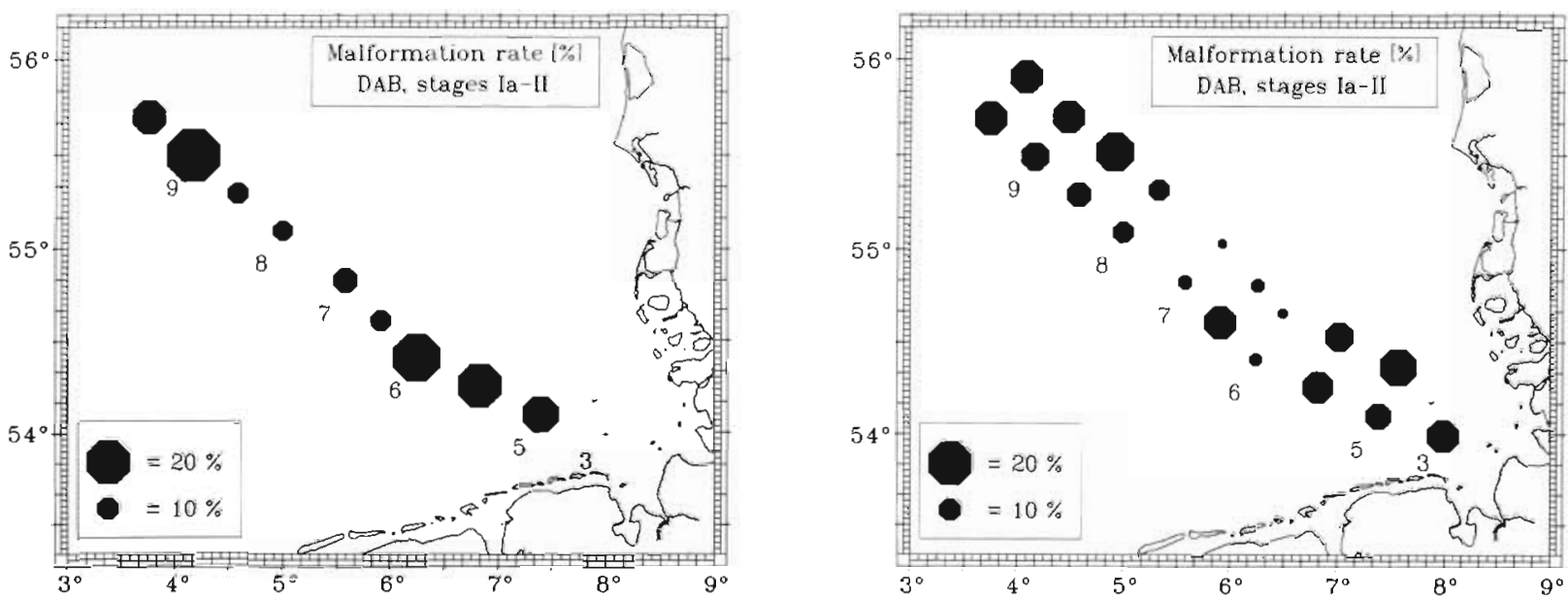

Fig. 3. Limanda limanda. Morphological malformation frequencies of dab at developmental stages Ia to II

in the inner part of the German Bight, declining offshore to values of $8.9 \%$ (Stn 8 ), but rising again to $30.6 \%$ on the Dogger Bank (Stn 9). In order to get a more complete spatial resolution and in order to increase the number of stations with sufficient eggs for evaluation, we took developmental stages la to II into account (Fig. 3). The resulting picture was similar with high aberration frequencies (16.5 to $21.8 \%$ ) at the inshore stations (Stns 3 to 6 ), lower values ( 4.5 to $15.0 \%$ ) at the reference Stns $7 \& 8$, and a higher frequency of $24.6 \%$ at the Dogger Bank (Stn 9). In comparison with the mean malformation frequency of $12.3 \%$, all the stations southeast of Stn 6 (Elbe influence) as well as northwest of the station between 8 and 9 (Dogger Bank) had higher values, whereas the frequencies at the reference Stns $7 \& 8$ were below the mean during all 3 transect investigations.

The differences from the mean frequencies were tested with a 4 -squares $\mathrm{Chi}^{2}$-test $(\mathrm{p}<0.05)$. On the way offshore (Fig. 1; March 16 to 18), the station between 5 and 6 as well as Stn 9 had significantly higher values compared to the mean, whereas $\operatorname{Stn} 8$ and the station between 8 and 9 had significantly lower values. The second part of the cruise (Fig 1 ; March 18 to 21) showed significantly higher malformation frequencies at the stations northwest, northeast and east of Stn 9 (near the Dogger Bank) as well as at Stn 3 and at the stations west and northeast of $\operatorname{Stn} 5$ (inshore). Significantly lower values were detected at Stns $6 \& 7$ and at the 3 stations northeast of these.

Anaphase aberration frequencies in Limanda $l i$ manda embryos reached a maximum of $63.4 \%$ in the inner part of the German Bight (Stn 3), then declined to $60.7 \%(\operatorname{Stn} 5), 58.2 \%(\operatorname{Stn} 6), 53.5 \%(\operatorname{Stn} 7)$ down to the lowest value with $51.0 \%$ at the less polluted Stn 8 . Significant differences occurred between Stns $3 \& 5$. on the one hand, compared to Strns $7 \& 8$, on the other hand, using a 4 -squares $\mathrm{Chi}^{2}$-test $(\mathrm{p}<0.01)$. On the Dogger Bank, values were found to be as high as $56.9 \%$.

\section{DISCUSSION}

An array of conditions can cause malformations in fish embryos. Among the natural factors are high and low water temperature, low salinity and low oxygen (Westernhagen 1970, Alderdice \& Forrester 1971, Braum 1973). When comparing the hydrographic data registered during the cruise with the tolerance limits determined for the respective fish embryos, it became apparent that the hydrographic conditions had not been critical for normal embryonic development.

There is a wealth of information on the experimentally determined influence of pollutants such as chlorinated hydrocarbons on the development and the reproductive capacity of fish (Allison et al. 1964, Hogan \& Brauhn 1975), and some investigations exist on the impairment of reproduction caused by contaminants occurring in the field (Westernhagen et al. 1981, 1989, Hansen et al. 1985, Spies \& Rice 1988). The development of the embryo may be disturbed by contaminants entering the egg during the time of maturation in the female gonads, or pollutants may interfere with development after the release of the spawning product into the surrounding water before and after fertilization. Actual contaminant concentrations in the water column are probably too low to cause acute effects, but the surface microlayer is known to affect the embryonic survival of fish eggs due to several potentially effective substances accumulated in this medium (Kocan et al. 1987. Westernhagen et al. 1987) 
Among the contaminants that can be considered as having an influence on reproductive capacity are chlorinated and aromatic hydrocarbons as well as heavy metals. It has been suggested that concentrations of chlorinated hydrocarbons in fish ovaries from the southern North Sea are responsible for an impairment of reproductive capacity due to increased prelarval mortality in whiting Merlangus merlangus (Westernhagen et al. 1989), flounder Platichthys flesus and dab Limanda limanda (Cameron \& Westernhagen unpubl.). Breeding experiments with $M$. merlangus also showed a positive relationship between anaphase aberrations in embryos and the contamination of PCB and DDE in parental gonads and liver (Dethlefsen et al. 1987). The data from the analysis of female $L . ~ l i$ manda liver obtained during the workshop show high values of chlorinated hydrocarbons, especially of the chlorinated biphenyl congeners 138, 153 and 180 from the inner part of the German Bight (Cofino et al. 1992) which could be responsible for the reduction in hatching success of larvae from contaminated parents.

The first quantitative investigation in the field on the occurrence of defective fish embryos with morphological as well as chromosomal deviations from normal development was conducted in the inner part of the Balsfjord in northern Norway (Kjörsvik et al. 1984). During the spawning season in 1983, morphological malformations in cod Gadus morhua embryos reached $20 \%$ in young developmental stages. Even embryos which appeared normal sometimes had severe chromosome aberrations. In March 1987, morphological malformation frequencies in the early developmental stage in Limanda limanda in the southeastern North Sea varied between 23 and $85 \%$ with maximum values occurring northwest of Helgoland, near the dumping area for wastes from the production of titanium dioxide, as well as off the Rhine estuary (Cameron et al. 1990).

Yannopoulos \& Yannopoulos (1981) described lethal morphological abnormalities in eggs of pilchard Sardina pilchardus (12\%) and anchovy Engraulis enchrasicolus $(9 \%)$ in the Aegean Sea. Investigations in the New York Bight (Longwell et al. 1984) on the cytologic and cytogenetic status of mackerel embryos Scomber scombrus showed elevated malformation frequencies up to $87 \%$ in early developmental stages with up to $86 \%$ mitotic abnormalities, which was attributed by the authors to pollution of the sea surface water. High values of aromatic and chlorinated hydrocarbons as well as of heavy metals could be determined as the main reasons for morphological embryonic malformations as well as for mitotic abnormalities in all developmental stages (Chang \& Longwell 1984). For the years 1979 to 1982 , Graumann \& Sukhorukova (1986) discovered severe morphological anomalies in older cod
Gadus morhua (36\%) and sprat Sprattus sprattus (25\%) embryos in the central and eastern Baltic. Oil pollution of the Baltic was discussed as a potential causative agent. In spring 1983 and 1984, a survey of pelagic fish eggs was conducted by Westernhagen et al. (1988) in the western Baltic. There a considerable amount of all embryos studied displayed aberrant morphological development, ranging from $28 \%$ in plaice Pleuronectes platessa over $32 \%$ in cod Gadus morhua to $44 \%$ in flounder Platichthys flesus. Anthropogenic factors were discussed as possible reasons for the occurrence of defective fish embryos.

Looking at the overall situation of fish recruitment in the southern North Sea, no stock-endangering impairment of recruitment appears to exist at present, despite the fact that at certain sites high malformation frequencies have been observed. It is well known that natural mortality in fish embryos and larvae is generally considerable (Harding \& Talbot 1973, Koslow et al. 1987. Westernhagen et al. 1988), and populations have to deal with relatively high variability in egg and larvae production and survival. Since year-class size is not a simple function of egg production (see Sinclair 1988), the effects of additional losses of eggs on recruitment due to teratogenic effects are difficult to assess. A potential effect on recruitment cannot be excluded, particularly if contaminant concentrations increase. Calculations of mortality rates in cod Gadus morhua embryos from the Baltic (Westernhagen et al. 1988 revealed a decrease of newly hatched larvae by $50 \%$ due to additional mortality caused by embryonic malformations. Even mortalities up to $100 \%$ in the case of the mackerel stock off the North American coast do not necessarily lead to the extinction of the population, because recruitment is assured by drifting and migration of eggs and larvae from unpolluted areas (Longwell et al. 1984).

Because of their great sensitivity towards pollutants, fish embryos and larvae have widely been used in experimental toxicity studies (Rosenthal \& Alderdice 1976. Westernhagen 1988). In this study it could be shown that fish embryos also respond to a deteriorating environmental situation in the field, displaying higher malformation frequencies in areas where Lohse (1990) and Schmidt (1988) found high concentrations of several contaminants. The same reaction by fish eggs could be shown for some areas of the Baltic as well as for the New York Bight (Longwell et al. 1984, Graumann 1986, Westernhagen et al. 1988). Thus, fish eggs may very well be used as indicators of water quality, and the investigations on morphological malformations of pelagic fish embryos are well suited for biological effects monitoring. The investigations on chromosomal aberrations in the same material as used for the determination of morphological aberrations 
provide the additional opportunity to evaluate the potential effects of contaminants on the chromosomal level, whereas its practical use is limited by the timeconsuming work. In particular, dab Limanda limanda with its wide distribution in the southeastern North Sea and a long spawning season is adequately suited to follow man-made changes in this marine environment, even though $L$. limanda may not be the most sensitive species as far as the frequency of embryo malformations is concerned.

Acknowledgement. This article contains parts of a doctoral study by P. Cameron in the Faculty of Biology, Hamburg University, Germany.

\section{LITERATURE CITED}

Alderdice, D. F., Forrester, C. R. (1971). Effects of salinity, temperature, and dissolved oxygen on early development of the Pacific cod (Gadus macrocephalus). J. Fish. Res. Bd Can. 28: 883-902

Allison, D., Kallman, B. J., Cope, O. B., van Valin, C. C. (1964). Some chronic effects of DDT on cutthroat trout. U.S. Bur. Sport Fish. Wildl., Res. Rep. 64

Braum, E. (1973). Einflüsse chronischen exogenen Sauerstoffmangels auf die Embryogenese des Herings (Clupea harengus). Neth. J. Sea Res. 7: 363-375

Bruggeman, W. A., Martron, L. B. J. M., Kooiman, D., Hutzinger, O. (1981). Accumulation and elimination kinetics of di-, tri- and tetra-chlororbiphenyls by goldfish after dietary and aqueous exposure. Chemosphere 10: 811-832

Cameron, P., Berg. J., Westernhagen, H. von, Dethlefsen, V. (1990). Mißbildungen bei Fischembryonen der südlichen Nordsee. In: Lozan, J., Lenz, W., Rachor, E., Watermann, B., Westernhagen, $H$. von (eds.) Warnsignale aus der Nordsee. Verlag Paul Parey, Berlin, Hamburg, p. 281-294

Chang, S., Longwell, A. (1984). Examining statistical associations of malformation, cyto-pathology and cytogenetic abnormality of Atlantic mackerel embryos with indicator levels on environmental contaminants in the New York Bight. C.M./ICES, E11: 1-9

Cofino, W. P., Smedes, F., de Jong, S. A., Abarnou, A., Boon, J. P., Oostingh, I. M., Davies, I., Klungsøyr, J., Wilhelmsen, S., Law, R. J., Whinnett, J. A., Schmidt, D., Wilson, S. (1992). The chemistry programme. Mar Ecol. Prog. Ser. 91: $47-56$

Dawson, A. S., Grimm, A. S. (1980). Quantitative seasonal changes in the protein, lipid and energy content of the carcass, ovaries and liver of adult female plaice, Pleuronectes platessa L. J. Fish Biol. 16: 493-504

Delahunty, G., de Vlaming, V. L. (1980). Seasonal relationships of ovary weight, liver weight and fat stores with body weight in the goldfish, Carassius auratus (L.). J. Fish Biol. 16: 5-13

Dethlefsen, V., Cameron, P., Westernhagen, H. von, Janssen, D. (1987). Morphologische und chromosomale Untersuchungen an Fischembryonen der südlichen Nordsee in Zusammenhang mit der Organochlorkontamination der Elterntiere Veröf. Inst. Küst.- u. Binnenfisch. Hamburg 97: 1-57

Graumann, G. B., Sukhorukova, L. (1982). On the emergence of sprat and cod abnormal embryos in the open Baltic. C. M./ICES, J7. 1-9

Hansen, P.-D., Westernhagen, H. von, Rosenthal, H. (1985).
Chlorinated hydrocarbons and hatching success in spring spawners of Baltic herring. Mar. environ. Res. 15: 59-76

Harding, D., Talbot, J W. (1973). Recent studies on the eggs and larvae of the plaice (Pleuronectes platessa L.) in the southern Bight. Rapp. P.-v. Réun. Cons. Int. Explor. Mer 164: 261-269

Hogan, J. W., Brauhn, J. L. (1975). Abnormal rainbow trout fry from eggs containing high residues of a PCB (Arochlor 1242). Progr. Fish Cult. 37: 229-230

Kersten, M., Dicke, M., Kriews, M., Naumann, K., Schmidt, D., Schulz, M., Schwikowski, M., Steiger, M. (1988). Distribution and fate of heavy metals in the North Sea. In: Salomons, W., Bayne, B. L., Duursma, E. K., Förstner, U. (eds.) Pollution of the North Sea. Springer-Verlag, Berlin, p. $300-347$

Kjörsvik, E., Stene, A., Lönning, S. (1984). Morphological, physiological and genetical studies of egg quality in cod (Gadus morhua). Floedevigen Rapp. 1: 67-86

Knickmeyer, R., Steinhart, H. (1989). On the distribution of polychlorinated biphenyl congeners and hexachlorobenzene in different tissues of dab (Limanda limanda) from the North Sea. Chemosphere 19: 1309-1320

Kocan, R. M., Westernhagen, H. von, Landolt, M. L. (1987). Toxicity of sea-surface microlayer: effects of hexane extracts on Baltic herring (Clupea harengus) and Atlantic cod (Gadus morhua) embryos. Mar. environ. Res. 23: 291-305

Koslow, J. A., Thompson, K. R., Silvert, W. (1987). Recruitment to northwest Atlantic cod (Gadus morhua) and haddock (Melanogrammus aeglefinus) stocks: influence of stock size and climate. Fish. Aquat. Sci. 44: 26-39

Lohse, J. (1990). Chlorierte organische Verbindungen in Wasser und Sediment. In: Lozan, J., Lenz, W., Rachor, E., Watermann, B., Westernhagen, H. von (eds.) Warnsignale aus der Nordsee. Verlag Paul Parey, Berlin, Hamburg, p. $75-85$

Longwell, A. C., Perry, D., Hughes, J., Hebert, A. (1984). Embryological, cyto-pathological and cytogenetic analysis of '74,'77 and '78 planktonic Atlantic mackerel eggs in the New York Bight. C.M./ICES, E13: 1-8

Rosenthal, H., Alderdice, D. F. (1976). Sublethal effects of environmental stressors, natural and pollutional, on marine fish eggs and larvae. J. Fish. Res. Bd Can. 33: 2047-2065

Schmidt, D. (1988). Trace metal distributions in sea water: two surveys covering the entire North Sea. C.M./ICES, E35: $1-9$

Sinclair, M. (1988). Marine populations: an essay on population regulation and speciation. Books in Recruitment Fishery Oceanography. University of Washington Press, Seattle, London, p. 252

Southward, A. J., Demir, N. (1974). Seasonal changes in dimensions and viability of the developing eggs of the Cornish pilchard (Sardina pilchardus Walbaum) off Plymouth. In: Blaxter, J. H. S. (ed.) The early life history of fish. Springer, Berlin, p. 53-68

Spies, R. B., Rice, D. W. (1988). Effects of organic contamination on reproduction of the starry flounder (Platichthys stellatus) in San Francisco Bay. II. Reproductive success of fish captured in San Francisco Bay and spawned in the laboratory. Mar. Biol 98: 191-200

Westernhagen, H. von (1970). Erbrütung der Eier von Dorsch (Gadus morhua), Flunder (Pleuronectes flesus) und Scholle (Pleuronectes platessa) unter kombinierten Temperatur- und Salzgehaltsbedingungen. Helgoländer wiss. Meeresunters. 21:21-102

Westermhagen, H. von (1988). Sublethal effects of pollutants on fish eggs and larvae. In: Hoar, W. S., Randall, D. J. 
(eds.) The physiology of developing fish. Fish physiology II. Academic Press, New York, p. 253-346

Westernhagen, $\mathrm{H}$. von, Cameron, P., Dethlefsen, V., Janssen, D. (1989). Chlorinated hydrocarbons in North Sea whiting (Merlangius merlangius L.), and effects on reproduction. I. Tissue burden and hatching success. Helgoländer Meeresunters. 43: 45-60

Westernhagen, H. von, Dethlefsen, V., Cameron, P., Berg, J., Fürstenberg, G. (1988). Developmental defects in pelagic fish embryos from the western Baltic. Helgoländer Meeresunters. 42: 13-36
Westernhagen, H. von, Landolt, M., Kocan, R., Fürstenberg, G., Jannssen, D., Kremling, K. (1987). Toxicity of sea-surface microlayer: I. Effects on herring and turbot embryos. Mar. environ. Res. 23: 273-290

Westernhagen, H. von, Rosenthal, H., Dethlefsen, V., Ernst, W., Harms, U., Hansen, P.-D. (1981). Bioaccumulating substances and reproductive success in Baltic flounder (Platichthys flesus L.). Aquat. Toxicol. 1: 85-99

Yannopoulos, A., Yannopoulos, C. (1981). Fish egg mortality and abnormal embryogenesis. Rapp. P.-v. Réun. int. Explor. scient. Mer Mediterr. 27(5): 143-146 